\title{
KEMAMPUAN MENULIS CERITA FANTASI SISWA KELAS VII SMP NEGERI SATU ATAP 1 MAROBO
}

\author{
Juriani Musurifu Hasina ${ }^{1}{ }$ Haerun Ana $^{2}$, dan Fahruddin Hanafi ${ }^{3}$ \\ pbsi.fkip.uho@gmail.com \\ 1,2,3, Jurusan Pendidikan Bahasa dan Sastra Indonesia, \\ Fakultas Keguruan dan Ilmu Pendidikan, Universitas Halu Oleo \\ Kampus Hijau Bumi Tridharma Anduonohu, Kendari, Indonesia
}

\begin{abstract}
ABSTRAK
Masalah dalam penelitian ini adalah Bagaimanakah kemampuan siswa menulis cerita fantasi pada aspek kesesuaian isi dengan judul, aspek orientasi, aspek komplikasi, aspek resolusi, aspek kata ganti/nama orang, aspek pilihan kata,aspek kata sambung urutan waktu, ungkapan kata/terkejut, dan aspek penggunaan dialog/kalimat langsung?Tujuan penelitian ini adalah untuk mendeskripsikan kemampuanmenulis cerita fantasi pada aspek kesesuaian isi dengan judul, aspek orientasi, komplikasi, aspek resolusi, aspek kata ganti/nama orang, aspek pilihan kata, aspek kata sambung urutan waktu, ungkapan kata terkejut, dan aspek penggunaan dialog/kalimat langsung. Jenis penelitian yang digunakan tergolong penelitian lapangan.Metode yang digunakan adalah metode deskriptif kuantitatif.Berdasarkan hasil analisis data, dapat disimpulkan bahwa kemampuan menulis cerita fantasi siswa kelas VII SMP Negeri Satu Atap 1 Marobo Kabupaten Muna berada dalam kategori mampu secara individual. Hal ini dibuktikan dari 61 siswayang dijadikan sampel penelitian, terdapat 53 orang siswa $(86,88 \%)$ yang masuk dalam kategori mampu secara individual dan terdapat 8 orang siswa $(13,12 \%)$ masuk dalam kategori belum mampu secara individual. Secara klasikal, kemampuan menulis cerita fantasi siswa kelas VII SMP Negeri Satu Atap 1 Marobo Kabupaten Muna masuk dalam kategori mampu secara klasikal. Dikatakan mampu karena siswa yang secara individual mencapai kemampuan minimal 70\% sebesar $86,88 \%$ mencapai kategori mampu secara klasikal yaitu 85\%.Dilihat dari tingkat kemampuan siswa kelas VII SMP Negeri Satu Atap 1 Marobo Kabupaten Muna pada setiap aspek penilaian, aspek resolusi, aspek kata sambung urutan waktu dan aspek ungkapan kata terkejut tuntas secara klasikal, karena telah mencapai ketuntasan klasikal 85\%. Sedangkan aspek kesesuaian isi dengan judul, aspek orientasi, komplikasi, kata ganti/nama orang, pilihan kata dan penggunaan dialog/kalimat langsung tidak tuntas secara klasikal karena belum mencapai ketuntasan klasikal 85\%. Aspek penggunaan kata ungkapan terkejut berada pada persentase terbaik, yaitu $(91,80 \%)$, aspek penulisan resolusi $(88,52 \%)$, aspek penggunaan kata sambung urutan waktu $(86,88 \%)$,aspek penulisan kata ganti/nama orang $(65,57)$, aspek kesesuaian isi dengan judul $(63,93 \%)$, aspek penulisan komplikasi (63,93\%), aspek penulisan orientasi $(59,01 \%)$, aspek pilihan kata $(55,73 \%)$, dan aspek penggunaan dialog/kalimat langsung berada pada peringkat terendah dengan mencapai prsentase $(45,90 \%)$.
\end{abstract}

Kata kunci: cerita fantasi; kemampuan, menulis; karangan

196 | Jurnal BASTRA (Bahasa dan Sastra), Vol. 5 No.2, Edisi April 2020/e-ISSN: 25033875 /http://ojs.ohu.ac.id/index.php/BAS 


\begin{abstract}
The problem in this research is how the students' ability to write fantasy stories on the aspect of suitability of the content with the title, orientation aspects, complications aspects, aspects of resolution, aspects of pronouns / names of people, aspects of word choice, aspects of conjunctions of time sequence, word expressions / surprise, and aspects of using direct dialogue / sentences? The purpose of this research is to describe the ability to write fantasy stories on the aspects of suitability of the content with the title, orientation aspects, complications, aspects of resolution, aspects of pronouns I names of people, aspects of word choice, aspects of conjunctions of time sequence, words of surprise, and aspects of dialogue usage. /direct sentence. This type of research is classified as field research. The method used is descriptive quantitative method. Based on the results of data analysis, it can be concluded that the ability to write fantasy stories of seventh grade students of SMP Negeri Satu Atap 1 Marobo, Muna Regency is in the individually capable category. This is evidenced by the 61 students who were used as the research sample, there were 53 students $(86.88 \%)$ who were in the capable category individually and there were 8 students $(13.12 \%)$ who were categorized as unable individually. Classically, the ability to write fantasy stories of seventh grade students of SMP Negeri Satu Atap 1 Marobo, Muna Regency, falls into the classically capable category. It is said to be capable because students who individually achieve at least $70 \%$ ability of $86.88 \%$ reach the classically capable category, namely $85 \%$. It can be seen from the ability level of class VII students of SMP Negeri One Roof 1 Marobo, Muna Regency in every aspect of assessment, aspect of resolution, aspect the conjunctive order of the time and the aspect of the expression of the words surprised completely classically, because it has reached $85 \%$ classical completeness. Meanwhile, the aspect of content conformity with the title, orientation aspect, complications, pronouns / names of people, choice of words and use of direct dialogue / sentence are not classically complete because they have not reached $85 \%$ classical completeness. The aspect of using surprised expressions is in the best percentage, namely (91.80\%), the aspect of writing resolution $(88.52 \%)$, the aspect of using conjunctions of time sequence $(86.88 \%)$, the aspect of writing pronouns / people's names $(65,57)$, the aspect of content suitability with the title $(63.93 \%)$, the complication writing aspect (63.93\%), the orientation writing aspect $(59.01 \%)$, the word choice aspect (55.73\%), and the dialogue usage aspect. I direct sentence is in the lowest rank by reaching the percentage (45.90\%).
\end{abstract}

Key words: fantasy story; ability, writing; essay

197 I Jurnal BASTRA (Bahasa dan Sastra), Vol. 5 No.2, Edisi April 2020/e-ISSN: 25033875 /http://ojs.ohu.ac.id/index.php/BAS 


\section{PENDAHULUAN}

Mata pelajaran bahasa Indonesia meliputi empat keterampilan berbahasa, yakni keterampilan menyimak, keterampilan berbicara, keterampilan membaca, keterampilan menulis. Keempat keterampilan tersebut masingmasing memiliki fungsi yang berbeda.Untuk komunikasi secara lisan orang menggunakan keterampilan menyimak dan berbicara, sedangkan komunikasi secara tertulis orang menggunakan keterampilan membaca dan menulis.

Menurut Mahsun (2014: 94) Pembelajaran bahasa Indonesia dalam kurikulum 2013 diorientasikan pada pelajaran berbasis teks, seperti dilihat dalam rumusan kopetensi dasar. Dengan demikian pemebelajaran berbasis teks yang diajarkan bukan sekedar pengetahuan berbahasa, melainkan berfungsi sebagai sumber aktualisasi diri.

Keterampilan menulis merupakan kegiatan yang sangat penting dalam pendidikan karena dapat membantu siswa dalam berpikir, mengungkapkan gagasan, dan memecahkan masalah. Menulis adalah salah satu bentuk berpikir, yang juga merupakan alat untuk membuat orang lain (pembaca) berpikir. Dengan menulis, siswa mampu mengkonstruk berbagai ilmu atau penegtahuan yang dimiliki dalam sebuah tulisan, baik dalam bentuk esai, artikel, laporan ilmiah, cerpen, puisi, dan sebagainya, Rosidi (2009: 3).

Keterampilan menulis adalah keterampilan yang paling kompleks, karena keterampilan menulis merupakan suatu proses perkembangan yang menuntut pengalaman, waktu, kesepakatan, latihan serta memerlukan cara berpikir yang teratur untuk mengungkapkannya dalam bentuk bahasa tulis.
Cerita fantasi merupakan sebuah karya tulis yang dibangun menggunakan alur cerita yang normal, namun memiliki sifat imajinatif dan khayalan semata.Yang menjadi acuan dalam penelitian ini adalah jenis narasi artistik atau narasi sugestif, yang merupakan sebuah teks karangan yang selalu melibatkan daya khayal atau imajinasi.

Teks narasi (cerita fantasi) merupakan salah satu jenis teks dalam pembelajaran bahasa Indonesia pada jenjang SMP/MTs kelas VII semester 1 . Dalam pembelajarn menyajikan cerita fantasi terdapat salah satu materi pembelajaran yang dipelajari siswa yaitu tentang menulis cerita fantasi. Materi tersebut tertera pada silabus pembelajaran bahasa Indonesia yaitu pada Kopetensi Dasar (KD) 4.4 menyajikan gagasan kreatif dalam bentuk teks narasi (cerita fantasi) secara lisan dan tertulis dengan memperhatikan struktur dan penggunaan Bahasa.

Memilih SMP Negeri Satu Atap 1 Marobo Kabupaten Muna menjadi objek penelitian didasari suatu pertimbangan, bahwa SMP Negeri Satu Atap 1 Marobo adalah salah satu sekolah yang sudah menerapkan kurikulum 2013 dan belum pernah dilakukan penelitian tentang menulis cerita fantasi pada penerapan kurikulum 2013, sehingga sekolah tersebut menarik untuk dijadiakan objek penelitian.

Berdasarkan latar belakang yang telah diuraikan sebelumnya, maka yang menjadi permasalahan dalam penelitian ini adalah

1. Bagaimanakah kemampuan siswa menulis cerita fantasi pada aspek kesesuaian isi dengan judul?

2. Bagaimanakah kemampuan siswa menulis cerita fantasi pada aspek orientasi? 
3. Bagaimanakah kemampuan siswa menulis cerita fantasi pada aspek komplikasi?

4. Bagaimanakah kemampuan siswa menulis cerita fantasi pada aspek resolusi?

5. Bagaimanakah kemampuan siswa menulis cerita fantasi pada aspek kata ganti/nama orang?

6. Bagaimanakah kemampuan siswa menulis cerita fantasi pada aspek pilihan kata?

7. Bagaimanakah kemampuan siswa menulis cerita fantasi pada aspek kata sambung urutan waktu?

8. Bagaimanakah kemampuan siswa menulis cerita fantasi pada aspek ungkapan kata/terkejut?

9. Bagaimanakah kemampuan siswa menulis cerita fantasi pada aspek penggunaan dialog/kalimat langsung?

Tujuan penelitian ini adalah

1. Untuk mendeskripsikan kemampuan siswa menulis cerita fantasi pada aspek kesesuaian isi dengan judul.

2. Untuk mendeskripsikan kemampuan siswa menulis cerita fantasi pada aspek orientasi.

3. Mendeskripsikan kemampuan siswa menulis cerita fantasi pada aspek komplikasi.

4. Mendeskripsikan kemampuan siswa menulis cerita fantasi pada aspek resolusi.

5. Untuk mendeskripsikan kemampuan siswa menulis cerita fantasi pada aspek kata ganti /nama orang.

6. Mendeskripsikan kemampuan siswa menulis cerita fantasi pada aspek pilihan kata.

7. Mendeskripsikan kemampuan siswa menulis cerita fantasi pada aspek kata sambung urutan waktu.
8. Mendeskripsikan kemampuan siswa menulis cerita fantasi pada aspek ungkapan kata/terkejut.

9. Mendeskripsikan kemampuan siswa menulis cerita fantasi pada aspek penggunaan dialog/kalimat langsung.

Manfaat yang diharapkan dalam penelitian ini adalah sebagai berikut:

1. Sebagai bahan informasi bagi guru bahasa Indonesia dalam proses belajar mengajar siswa khususnya menulis cerita fantasi.

2. Bermanfaat untuk meningkatkan kualitas siswa dan sebagai bahan masukan bahwa pemahaman karya sastra dalam bentuk cerita fantasi sangat penting dalam dunia pendidikan khusunya mata pelajaran bahasa Indonesia.

3. Sebagai bahan peningkatan kualitas pembelajaran di sekolah dan meningkatkan prestasi siswa dalam hal menulis.

4. Sebagai bahan informasi bagi peneliti lain yang ingin mengadakan penelitian yang relevan mengenai pembelajaran menulis cerita fantasi.

\section{METODE DAN TEKNIK PENELITIAN}

Penelitian ini menggunakan deskriptif kuantitatif yaitu analisis data berdasarkan presentase. Analisis deskriptif kuantitatif mengambarkan hasil penelitian berdasarkan fakta objektif yang diperoleh siswa dikelas berupa tes menulis cerita fantasi Siswa Kelas VII SMP Negeri Satu Atap 1 Marobo Kabupaten Muna

Ditinjau dari jenisnya, penelitian ini dikategorikan penelitian lapangan.dikatakan demikian, karena peneliti terlibat secara langsung ke sekolah yakni SMP Negeri Satu Atap 1 
Marobo untuk memperoleh data penelitian.

Populasi dalam penelitian ini adalah seluruh siswa kelas VII SMP Negeri Satu Atap 1 Marobo Kabupaten Muna Tahun Pelajaran 2018/2019 yang berjumlah 61 siswa yang tesebar dalam dua kelas dengan rincian sebagai berikut.

Tabel 1.1

Populasi Penelitian Siswa Kelas VII

SMP Negeri Satu Atap 1 Marobo

Kabupaten Muna

Jumlah Siswa

No Kelas Laki- Perempuan Jumlah laki

\begin{tabular}{lllll}
\hline 1 & VII 1 & 14 & 17 & 31 \\
\hline 2 & VII 2 & 16 & 14 & 30 \\
\hline
\end{tabular}

Jumlah

Tahun Pelajaran2018/2019)

Penentuan sampel yang digunakan dalam penarikan sampel ini yaitu menggunakan teknik total sampling yakni jumlah sampel diambil secara keseluruhan dari jumlah populasi yang ada.

Untuk mengetahui tentang kemampuan menulis cerita fantasi siswa kelas VII SMP Negeri Satu Atap 1 Marobo, penelitian ini menggunakan instrumen tes menulis.Siswa diberikantema persahabatan kemudian dikembangkan oleh siswa dengan memperhatikan aspek kesesuaian isi dengan judul, kelengkapan struktur (orientasi, komplikasi, Resolusi), ciri kebahasan cerita fantasi (kata ganti orang, pilihan kata, kata sambung urutan waktu, ungkapan kata terkejut, dan penggunaan dialog/kalimat langsung) dengan bahasa mereka sendiri dan masih menggunakan ejaan dan tanda baca yang benar. Menggunakan tes menulis karena dapat mempermudah peneliti untuk mengetahui keterampilan siswa dalam menulis cerita fantasi dari tema yang telah diberikan

Langkah-langkah yang digunakan dalam pengumpulan data penelitian ini adalah sebagai berikut.

1. Mengecek atau memeriksa objek penelitian yang hadir dalam kelas.

2. Menyarankan siswa agar lebih tenang dan tertib pada saat berada dalam ruangan.

3. Siswa menyiapkan alat-alat tulis yang mendukung kegiatan menulis.

4. Membagikan kertas instrumen penelitian kepada siswa.

5. Memberikan kesempatan untuk bertanya tentang petunjuk instrumen.

6. Siswa diberi kesempatan menulis cerita fantasi berdasarkan tema yang telah disediakan.

7. Waktu yang disediakan $2 \times 40$ menit atau dua jam pelajaran dengan alokasi waktu, pengenalan sekaligus menjawab pertanyaan siswa yang berkaitan dengan petunjuk instrumen selama 10 menit dan waktu mengerjakan soal 70 menit.

8. Setelah waktu yang diberikan selasai, lembar kerja siswa dikumpul dan selanjutnya peneliti melakukan koreksi hasil tulisan siswa.

Teknik yang digunakan untuk menilai tulisan siswa adalah Teknik analitik, penilaian berdasarkan unsurunsur skala yaitu 1-4.Skala penilaian tersebut mengacu pada penulisan teks cerita fantasi yang ditetapkan oleh pusat penilaian pendidikan Departemen Pendidikan Nasional yang diberlakukan di SMP Negeri Satu Atap 1 Marobo Kabupaten Muna. 
Analisis data yang digunakan dalam penelitian ini adalah teknik persentase dengan menggunakan angka-angka.Teknik persentase dilakukan untuk mengetahui kemampuan siswa dalam menulis cerita fantasi. Selanjutnya, untuk mengetahui tingkat kemampuan siswa dalam menulis cerita fantasi mengacu pada anggapan bahwa siswa dikatakan mampu secara individual apabila mempunyai kemampuan minimal $70 \%$ dari aspek yang dinilai, sedangkan tuntas belajar secara klasikal apabila siswa mencapai ketuntasan minimal $85 \%$. Hal ini berdasarkan KKM yang terdapat di SMP Negeri Satu Atap 1 Marobo Kabupaten Muna.Standar kelulusan atau siswa dikatakan mampu apabila siswa memperoleh standar KKM nilai 70.

\section{HASIL DAN PEMBAHASAN}

Penelitian ini dilakukan pada tanggal 5, 6, dan 7 November 2018 yang bertempat di SMP Negeri Satu Atap 1 Marobo. Peneliti melakukan penelitan pada keseluruhan siswa kelas VII yang terbagi dua kelas, setiap kelas terdiri dari 30 dan 31 siswa sehingga, jumlah 61 siswa pada kelas VII dijadikan peneliti sebagai sampel penelitian.

Kemampuan menulis cerita fantasi siswa kelas VII SMP Negeri Satu Atap 1 Marobo dari 61 responden dapat dijelaskan sebagai berikut.

1. Terdapat 53 orang siswa $(86,88 \%)$ memperoleh kategori mampu.

2. Terdapat 8 orang siswa $(13,12 \%)$ memperoleh kategori belum mampu.

Berdasarkan hasil pengelolahan data tentang kemampuan menulsi cerita fantasi siswa kelas VII SMP Negeri Satu Atap 1 Marobo pada aspek kesesuaian isi dengan judul menunjukan bahwa dari 61 orang siswa kelas VII SMP Negeri Satu Atap 1 Marobo, terdapat 39 orang Siswa $(63,93 \%)$ secara individual dikategorikan mampu dan terdapat 22 orang siswa $(36,07 \%)$ dikategorikan belum mampu.

Berdasarkan hasil pengelolahan data tentang kemampuan menulis cerita fantasi siswa kelas VII SMP Negeri Satu 1 Marobo Kabupaten Muna pada aspek orientasi menunjukan bahwa dari 61 orang siswa, terdapat 36 orang siswa $(59,01 \%)$ secara individual dikategorikan mampu dan terdapat 25 orang siswa $(40,99 \%)$ dikategorikan belum mampu.

Berdasarkan hasil pengelolahan data tentang kemampuan siswa kelas VII SMP Negeri Satu 1 Marobo Kabupaten Muna dalam menulis cerita fantasi pada aspek komplikasi menunjukan bahwa dari 61 orang siswa, terdapat 39 orang siswa $(63,93 \%)$ secara individual dikategorikan mampu dan terdapat 22 orang siswa $(36,07 \%)$ dikategorikan belum mampu.

Berdasarkan hasil pengelolahan data tentang kemampuan menulis cerita fantasi siswa kelas VII SMP Negeri Satu 1 Marobo Kabupaten Muna pada aspek resolusi menunjukan bahwa dari 61 orang siswa, terdapat 54 orang siswa $(88,52 \%)$ secara individual dikategorikan mampu dan terdapat 7 orang siswa $(11,48 \%)$ dikategorikan belum mampu.

Berdasarkan hasil pengelolahan data tentang kemampuan menulis cerita fantasi siswa kelas VII SMP Negeri Satu 1 Marobo Kabupaten Muna pada aspek kata ganti orang menunjukan bahwa dari 61 orang siswa, terdapat 40 orang siswa $(65,57 \%)$ secara individual dikategorikan mampu dan terdapat 21 
orang siswa $(34,43 \%)$ dikategorikan belum mampu.

Berdasarkan hasil pengelolahan data tentang kemampuan menulis cerita fantasi siswa kelas VII SMP Negeri Satu 1 Marobo Kabupaten Muna pada aspek pilihan kata menunjukan bahwa dari 61 orang siswa, terdapat 34 orang siswa $(55,73 \%)$ secara individual dikategorikan mampu dan terdapat 27 orang siswa (44,27\%) dikategorikan belum mampu.

Berdasarkan hasil pengelolahan data tentang kemampuan menulis cerita fantasi siswa kelas VII SMP Negeri Satu 1 Marobo Kabupaten Muna pada aspek kata sambung urutan waktu menunjukan bahwa dari 61 orang siswa, terdapat 53 orang siswa $(86,88 \%)$ secara individual dikategorikan mampu dan terdapat 8 orang siswa $(13,12 \%)$ dikategorikan belum mampu.

Berdasarkan hasil pengelolahan data tentang kemampuan menulis cerita fantasi siswa kelas VII SMP Negeri Satu 1 Marobo Kabupaten Muna pada aspek penggunaan kata ungkapan terkejut menunjukan bahwa dari 61 orang siswa, terdapat 56 orang siswa $(91,80 \%)$ secara individual dikategorikan mampu dan terdapat 5 orang siswa $(8,20 \%)$ dikategorikan belum mampu.

Berdasarkan hasil pengelolahan data tentang kemampuan menulis cerita fantasi siswa kelas VII SMP Negeri Satu 1 Marobo Kabupaten Muna pada aspek penggunaan dialog/kalimat langsung menunjukan bahwa dari 61 orang siswa, terdapat 28 orang siswa $(45,90 \%)$ secara individual dikategorikan mampu dan terdapat 33 orang siswa $(54,10 \%)$ dikategorikan belum mampu.
Tabel 2.1

Interpretasi Kemampuan Menulis Cerita Fantasi Siswa Kelas VII SMP Negeri Satu Atap 1 Marobo Kabupaten Muna

\begin{tabular}{|c|c|c|c|}
\hline $\mathrm{No}$ & $\begin{array}{c}\text { Aspek } \\
\text { Penilaian }\end{array}$ & $\begin{array}{c}\text { Peresentase } \\
\text { Kemampua } \\
\mathrm{n}(\%)\end{array}$ & $\begin{array}{c}\text { Keteran } \\
\text { gan }\end{array}$ \\
\hline 1 & $\begin{array}{c}\text { Kesesuai } \\
\text { an Isi } \\
\text { dengan } \\
\text { Judul }\end{array}$ & $63,93 \%$ & $\begin{array}{l}\text { Belum } \\
\text { Mampu }\end{array}$ \\
\hline 2 & Orientasi & $59,01 \%$ & $\begin{array}{c}\text { Belum } \\
\text { Mampu }\end{array}$ \\
\hline 3 & $\begin{array}{c}\text { Komplika } \\
\text { si }\end{array}$ & $63,93 \%$ & $\begin{array}{l}\text { Belum } \\
\text { Mampu }\end{array}$ \\
\hline 4 & Resolusi & $88,52 \%$ & Mampu \\
\hline 5 & $\begin{array}{c}\text { Kata } \\
\text { Ganti/Na } \\
\text { ma } \\
\text { Orang }\end{array}$ & $65,57 \%$ & $\begin{array}{l}\text { Belum } \\
\text { Mampu }\end{array}$ \\
\hline 6 & $\begin{array}{c}\text { Pilihan } \\
\text { Kata }\end{array}$ & $55,73 \%$ & $\begin{array}{c}\text { Belum } \\
\text { Mampu }\end{array}$ \\
\hline 7 & $\begin{array}{c}\text { Penggun } \\
\text { aan Kata } \\
\text { Sambung } \\
\text { Urutan } \\
\text { Waktu } \\
\end{array}$ & $86,88 \%$ & Mampu \\
\hline 8 & $\begin{array}{c}\text { Penggun } \\
\text { aan Kata } \\
\text { Ungkapa } \\
\text { n } \\
\text { Terkejut }\end{array}$ & $91,80 \%$ & Mampu \\
\hline 9 & $\begin{array}{c}\text { Penggun } \\
\text { aan } \\
\text { Dialog/K } \\
\text { alimat } \\
\text { langsung }\end{array}$ & $45,90 \%$ & $\begin{array}{l}\text { Belum } \\
\text { Mampu }\end{array}$ \\
\hline
\end{tabular}




\section{DAFTAR PUSTAKA}

Abigail W, Monica. 2015. Belajar Menulis. Surabaya: JP Books.

Dalman. 2016. Keterampilan Menulis. Jakarta: Rajagrafindo Persada.

Harsiati, Dkk. 2017 a. Buku GuruBahasa Indonesia Edisi Revisi 2017. Jakarta: Pusat Kurikulum dan Perbukuan, Balitbang, Kemendikbud.

Harsiati, Dkk. 2017 b. Buku SiswaBahasa Indonesia Edisi Revisi 2017. Jakarta: Pusat Kurikulum dan Perbukuan, Balitbang, Kemendikbud.

Mahsun.2014. Teks Dalam Pembelajaran Bahasa Indonesia Kurikulum 2013. Jakarta: Rajagrafindo Persada.

Nurgiyantoro, Burhan. 2013. Sastra Anak Pengantar Pemahaman Dunia Anak. Yogyakarta: Gadja Mada University Press.

Rosidi, Imron. 2009. Menulis Siapa Takut. Yogykarta: Kanisius.

Soebachman, Agustina. 2016. Mahir Menulis Dalam 4 Hari. Yogyakarta: Kauna Pustaka.

Suparno, Mohamad Yunus. 2011. Keterampilan Dasar Menulis. Jakarta: Universitas Terbuka.

Tarigan, Henry Guntur. 2008. Menulis Sebagai Suatu Keterampilan Berbahasa. Bandung: Angkasa Bandung.

Wicaksono, Andri. 2014. Menulis Kreatif Sastra Dan Beberapa Model Pembelajarannya. Yogyakarta: Garudhawaca. 